\title{
ANALITYCZNY PROCES HIERARCHICZNY (AHP) NA SKRÓTY - KLUCZOWE POJĘCIA I LITERATURA ${ }^{4}$
}

\begin{abstract}
Współcześnie dość powszechnym kierunkiem aktywności badawczej i wdrożeniowej jest poszukiwanie nowych metod lub nowych sposobów wykorzystania metod znanych. Takim właśnie zagadnieniem zajęto się $\mathrm{w}$ niniejszym artykule. Analizie poddano jedną $\mathrm{z}$ metod wykorzystywanych w procesie podejmowania decyzji- Analytic Hierarchy Process (AHP). W Polsce jest ona przedmiotem badań. Natomiast aspekt wdrożenia do praktyki gospodarczej jest stosunkowo nowy. Prezentowany artykuł stanowi swoisty przegląd metody, przedstawiający najważniejsze informacje dla osób podejmujących próbę jej wykorzystania. Szczególnie interesujące wydaje się wykorzystanie omawianej metody w zarządzaniu strategicznym (podejmowanie decyzji strategicznych) zarówno w instytucjach publicznych, jak i w większych podmiotach gospodarczych.

Celem artykułu jest przedstawienie, przegląd i wyjaśnienie kluczowych pojęć związanych z jedną z najpopularniejszych na świecie metod wspomagania decyzji - analitycznym procesem hierarchicznym (AHP). Metoda ta została opracowana w latach siedemdziesiątych XX w. przez amerykańskiego matematyka Thomasa L. Saaty'ego. Artykuł porządkuje i objaśnia kluczowe pojęcia związane z AHP, przedstawione hasłowo jako: „hierarchia”, „eksperci-decydenci”, „porównania parami”, „priorytety”, „niezgodność”, „analiza wrażliwości” oraz „decyzje grupowe". W odniesieniu do każdego z tych tematów przedstawiono typowe problemy oraz źródła literaturowe.
\end{abstract}

Słowa kluczowe: analityczny proces hierarchiczny, AHP, niezgodność, CR, decyzje grupowe, decydenci.

\section{WPROWADZENIE}

Metoda analitycznego procesu sieciowego, znana także jako „metoda AHP” (Analytic Hierarchy Process), a także jej rozszerzenie analityczny proces sieciowy „ANP” (Analytic Network Process) to jedne $\mathrm{z}$ najpopularniejszych w świecie wielokryterialnych metod wspomagania decyzji. Zostały stworzone przez amerykańskiego matematyka, Thomasa L. Saaty'ego, w latach siedemdziesiątych XX w. Historia AHP zaczęła się jednak już w latach sześćdziesiątych XX w., kiedy Saaty odpowiadał za realizacje projektów w Amerykańskiej

\footnotetext{
${ }^{1}$ Dr Anna Prusak, Katedra Zarządzania Jakością, Uniwersytet Ekonomiczny w Krakowie, ul. Rakowicka 27, 31-510 Kraków, tel. (0-12) 29-35-583 autor korespondencyjny, e-mail: anna.prusak@uek.krakow.pl

${ }^{2} \mathrm{Dr}$ Jacek Strojny, Katedra Ekonomii, Politechnika Rzeszowska, Rzeszów, e-mail: jstrojny@prz.edu.pl

${ }^{3}$ Dr Piotr Stefanow, Katedra Statystyki i Demografii, Krakowska Akademia im. A. F. Modrzewskiego,e-mail: pstefanow@afm.edu.pl

${ }^{4}$ Badania zaprezentowane $\mathrm{w}$ artykule zostały sfinansowane ze środków Narodowego Centrum Nauki przyznanych na podstawie decyzji nr DEC-2011/01/D/HS4/04006.
} 
Agencji Kontroli Zbrojeń i Rozbrojenia. Nie będąc w pełni usatysfakcjonowany wynikami projektów, jako przyczynę niepowodzeń podał, między innymi, abstrakcyjność modeli decyzyjnych, które wówczas stosowano. Wtedy narodził się pomysł opracowania stosunkowo prostego, uniwersalnego narzędzia wspomagającego decydentów w podejmowaniu złożonych decyzji ${ }^{5}$. Sama idea „wspomagania decyzji”, czyli klasyfikacja decyzji przez rekomendację takiego działania, które jest optymalne pod względem celów i oczekiwań decydenta ${ }^{6}$, sięga już czasów starożytnych, czego przykładem jest słynna wyrocznia w Delfach. Jako przykład bardziej współczesnego podejścia do wspomagania decyzji podaje się list Benjamina Franklina z 1772 roku do Josepha Priestleya, angielskiego naukowca. W liście tym Franklin zalecał podzielenie kartki na dwie kolumny - argumenty ,za” oraz ,przeciw” decyzji. Po sporządzeniu listy należy sięzastanowić nad ważnością poszczególnych argumentów, skreślając $\mathrm{z}$ obu list po jednym równoważnym argumencie, a jeśli jeden powód „,za” zrównoważy się z dwoma ,przeciw”, wówczas należy wyeliminować wszystkie trzy ${ }^{7}$. W latach sześćdziesiątych i siedemdziesiatych XX w. powstało wiele metod wspomagających podejmowanie decyzji, oprócz AHP i ANP, były to między innymi ELECTRE, PROMETHEE \& GAIA, MACBETH, VDA. Jednakże żadna z tych metod nie osiąnęła takiej popularności jak metody Saaty'ego, które do dziś są powszechnie stosowane zarówno w nauce, jak i praktyce. Przykładem organizacji stosujących AHP w podejmowaniu decyzji są między innymi Departament Obrony Stanów Zjednoczonych, IBM, British Airways, Xerox, Ford $^{8}$. Popularność AHP wynika przede wszystkim z jej wszechstronności i uniwersalności, czego dowodem jest to, że była i jest stosowana w wielu różnych dziedzinach ${ }^{9}$. Ponadto daje się ją łączyć z innymi technikami i metodami, na przykład AHP/DEA ${ }^{10}$, AHP-TOPSIS ${ }^{11}$, Delphi-AHP ${ }^{12}$. Celem tego artykułu jest uporządkowanie i przedstawienie kluczowych pojęć związanych z AHP (a zarazem także ANP, która oparta jest na tym samym aparacie matematycznym). Motywem napisania artykułu w tej formie były między innymi pytania zadawane przez uczestników badań, prowadzonych przez autorów artykułu w zakresie

\footnotetext{
${ }^{5}$ E.H. Forman, S.I. Gass, The Analytic Hierarchy Process - An Exposition, „Operations Research” 49/4 (2001), s. 469-486.

${ }^{6}$ B. Roy, Paradigms and Challenges. In Multiple Criteria Decision Analysis: State of the Art Surveys, ,International Series in Operations Research \& Management Science” 2005/78, s. 3-24.

${ }^{7}$ L.W. Labaree, Mr. Franklin: A Selection from His Personal Letters by Benjamin Franklin, red. L.W. Labaree, W.J. Bell, Yale University Press, New Haven 1956.

${ }^{8}$ T.L. Saaty 2008a Relative Measurement and Its Generalization in Decision Making. Why Pairwise Comparisons are Central in Mathematics for the Measurement of Intangible Factors The Analytic Hierarchy/Network Process, RACSAM (Revista de La Real Academia de Ciencias Exactes, Fisicas Y Naturales. Serie A. Matematicas), 102/2 (2008), s. 251-318.

${ }^{9}$ O.S. Vaidya, S. Kumar, Analytic hierarchy process: An overview of applications, „European Journal of Operational Research" 169/1 (2006), s. 1-29.

${ }^{10} \mathrm{Z}$. Sinuany-Stern, An AHP/DEA methodology for ranking decision making units, „International Transactions in Operational Research" 7/2 (2000), s. 109-124.

${ }^{11}$ L. Gao, A. Hailu, Identifying preferred management options: An integrated agent-based recreational fishing simulation model with an AHP-TOPSIS evaluation method, „Ecological Modelling" 2013/249, s. 75-83.

${ }^{12}$ L.A. Vidal, F. Marle, J.-C. Bocquet, Using a Delphi process and the Analytic Hierarchy Process $(A H P)$ to evaluate the complexity of projects, „Expert Systems with Applications” 38/5 (2011), s. 5388-5405.
} 
zastosowania AHP, które dotyczą takich charakterystycznych dla tej metody zagadnień, jak „,hierarchia”, „eksperci-decydenci”, „porównania parami”, „priorytety”, „niezgodność”, ,analiza wrażliwości” oraz „,decyzje grupowe”. Aspekty te można potraktować jako punkty krytyczne, które powinien znać każdy użytkownik metody AHP/ANP. Artykuł nie tylko porządkuje, objaśnia i rozwija te pojęcia, ale też cytuje najbardziej charakterystyczne w tym zakresie pozycje literaturowe.

\section{HIERARCHIA}

Pierwszym krokiem zastosowania metody AHP jest budowa modelu decyzyjnego, zwanego w teorii AHP strukturą hierarchiczną lub hierarchią decyzyjną (od tego pochodzi nazwa procesu hierarchicznego). Jest to najbardziej kreatywny etap AHP, wymagający dużego nakładu czasu i wiedzy, a tym samym udziału odpowiednich ekspertów ${ }^{13}$. Budowa modelu hierarchicznego oparta jest na założeniu, że problem decyzyjny można zdekomponować na mniejsze elementy i przedstawić je w postaci hierarchii. Najczęściej spotykany w literaturze typ hierarchii w metodzie AHP to czteropoziomowa struktura złożona z celu decyzyjnego, umieszczonego na samym szczycie hierarchii, kryteriów decyzyjnych (zwanych też celami cząstkowymi), subkryteriów stanowiących uszczegółowienie kryteriów oraz wariantów decyzyjnych, zwanych również ,alternatywami” i umieszczonych w dolnej części hierarchii. Schemat takiej struktury przedstawiono na rysunku 1 . W książce The Hierarchon ${ }^{14}$ zamieszczono blisko 400 przykładów różnych modeli hierarchicznych dotyczących decyzji w różnych obszarach. Prawie wszystkie mają postać struktury czteropoziomowej, stąd można przyjąć, że za jej pomocą można rozwiązać większość problemów decyzyjnych.

Rys. 1. Czteropoziomowa hierarchia jako model najczęściej prezentowany w literaturze AHP

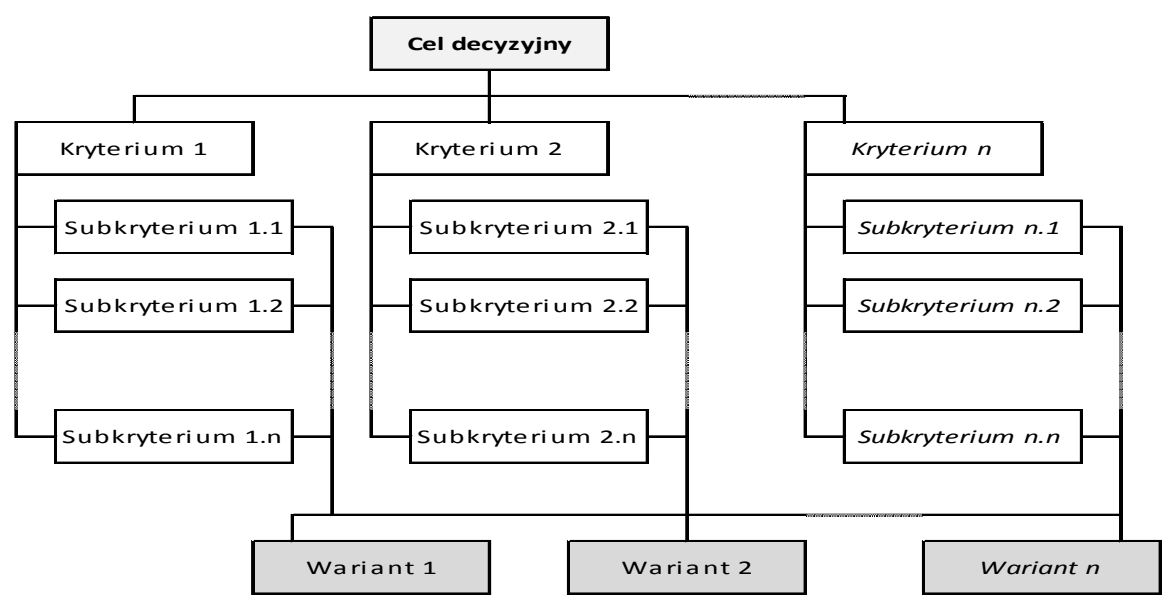

Źródło: Opracowanie własne.

\footnotetext{
${ }^{13}$ T.L. Saaty, Fundamentals of Decision Making and Priority Theory with the Analytic Hierarchy Process, wyd. 2, RWS Publications, Pittsburgh 2000.

${ }^{14}$ T.L. Saaty, E.H. Forman, The Hierarchon: A Dictionary of Hierarchies, RWS Publications, Pittsburgh 1992.
} 
Cel decyzyjny (goal) odpowiada na pytanie ,jaki stan decydent chce osiagnąć?”, i stanowi główny element hierarchii, wynikający bezpośrednio z problemu decyzyjnego. Dlatego powinien być określony na tyle konkretnie, aby udało się jednoznacznie zdefiniować wpływające na jego realizację warianty oraz kryteria decyzyjne. Na przykład cel sformułowany jako ,zakup samochodu” nie zawiera informacji, czy chodzi o samochód sportowy, czy bagażowy, czy nabywa go osoba fizyczna, czy firma itd. Tymczasem jest to istotne z punktu widzenia zarówno wariantów, jak i kryteriów wyboru samochodu, które będą zupełnie inne w tych dwóch wypadkach.

Warianty, w literaturze określane częściej (nie do końca poprawnie) jako alternatywy decyzyjne (alternatives), odpowiadają na pytanie ,jaki decydent ma wybór?” i są umieszczone na samym dole hierarchii. Stanowią zestaw co najmniej dwóch elementów, spośród których decydent ma dokonać wyboru (sama decyzja zaś definiowana jest jako świadomy i nielosowy wybór danego wariantu). Wariantem decyzyjnym może być nie tylko obiekt fizyczny (np. samochód), ale także mogą się na niego składać bardziej złożone opisy strategii działania czy sposobu rozwiązania problemów. Dla decydenta wybór danego wariantu wiąże się z osiagnięciem przez niego określonych konsekwencji, będących rezultatem wdrożenia tego wariantu ${ }^{15}$.

Kryteria decyzyjne (criteria) to elementy służące do oceny i porównania wariantów decyzyjnych ze względu na przyjęty punkt widzenia wyrażony za pomocą celu decyzyjnego. Złożone decyzje obejmują często dużą liczbę tych kryteriów, stad wzięło się określenie „decyzje i metody wielokryterialne”. W strukturze hierarchicznej AHP kryteriami są czynniki, które wpływają bezpośrednio na cel decyzyjny, dlatego są także określane jako „cząstkowe cele decyzyjne”. W zaprezentowanej już, czteropoziomowej hierarchii kryteria są dodatkowo uszczegółowione za pomocą subkryteriów (subcriteria). Istotą tak skonstruowanej analizy hierarchicznej jest wskazanie tego wariantu, który w najwyższym stopniu spełnia najważniejsze subkryteria oraz kryteria, a tym samym przyczynia się w najwyższym stopniu do realizacji celu decyzyjnego.

Bardziej złożone modele hierarchiczne mogą dodatkowo dekomponować subkryteria na sub-subkryteria, czy też wprowadzać dodatkowe kategorie elementów, na przykład interesariuszy $\mathrm{i}$ ich rolę $\mathrm{w}$ realizacji celu decyzyjnego ${ }^{16}$. Do podstawowych zalet każdego modelu hierarchicznego można zaliczyć pomoc w porządkowaniu i systematyzowaniu problemu decyzyjnego. Ponadto AHP jako jedna z nielicznych metod wielokryterialnych pozwala na stosowanie w jednym modelu hierarchicznym elementów materialnych (mierzalnych) i niematerialnych (niemierzalnych) ${ }^{17}$. Jednakże aby zbudować hierarchię, która ma być podstawą dalszej analizy, muszą zostać spełnione określone zasady budowy poprawnej struktury hierarchicznej ${ }^{18}$. Do najważniejszych z nich należą ,zasada $7 \pm 2$ " oraz ,zasada homogeniczności”. Zasada $7 \pm 2$ to tak zwana „liczba Millera”, która stanowi, że przeciętny człowiek nie jest w stanie przetworzyć naraz więcej niż 7 elementów informacji, przy czym są

\footnotetext{
${ }^{15}$ B. Roy, op. cit.

${ }^{16}$ R.F. Dyer, E.H. Forman, Group decision support with the Analytic Hierarchy Process, „Decision Support Systems" 8/2 (1992), s. 99-124.

17 E.H. Forman, Facts and fictions about the analytic hierarchy process, „Mathematical and Computer Modelling" 17/4-5 (1993), s. 19-26.

18 A. Prusak, P. Stefanów, AHP - analityczny proces hierarchiczny. Budowa i analiza modeli decyzyjnych krok po kroku, wyd. 1, C.H. Beck, Warszawa 2014.
} 
tacy, którzy są w stanie przetworzyć tylko 5, a nieliczni $-9^{19}$. Dlatego żadna grupa w modelu hierarchicznym nie powinna zawierać więcej niż 9 elementów ${ }^{20}$. Zasada homogeniczności zakłada dobór elementów w poszczególnych zbiorach według ich podobieństwa, czyli nie mogą się one znacząco od siebie różnić. $\mathrm{O}$ ile łatwo jest takie podobieństwo stwierdzić w odniesieniu do obiektów fizycznych, o tyle problematyczne staje się określenie podobieństwa cech niematerialnych. W takim wypadku należy odpowiedzieć na pytanie, czy cechy są ,tej samej klasy", a jeśli badacz uzna, że nie, wówczas powinien je odpowiednio rozdzielić na jednorodne zbiory ${ }^{21}$.

\section{EKSPERCI/DECYDENCI}

Prawie wszystkie metody wielokryterialne wspomagające podejmowanie decyzji wymagają udziału ekspertów w procesie decyzyjnym. Związane jest to ze skutkami, zasięgiem i złożonością podejmowanych decyzji ${ }^{22}$. Dlatego AHP można określić jako metodę ekspercka, przy czym zaleca się, aby eksperci byli w nią zaangażowani od momentu budowy modelu hierarchicznego. Ekspert to osoba posiadająca wiedzę i doświadczenie, które może być wykorzystane do rozwiązania danego problemu decyzyjnego. Bardzo częstym błędem w analizie decyzyjnej jest utożsamianie eksperta z decydentem. Tymczasem ,decydent” jest pojęciem szerszym, obejmującym następujące kategorie ${ }^{23}$ :

- decydenci formalni (,„właściwi”) - mocodawcy, którzy mają kompetencje do podjęcia ostatecznej decyzji, w oparciu na wynikach analizy decyzyjnej bądź niezależnie od nich;

- decydenci materialni - sponsorzy, zapewniający zaplecze finansowe i/lub infrastrukturalne niezbędne do wdrożenia decyzji;

- decydenci merytoryczni - eksperci, czyli doradcy, przygotowujący projekt decyzji, bardzo często wspomagani przez analityka, którego rolą jest wyłącznie wspomaganie eksperta w zastosowaniu właściwej metody podejmowania decyzji.

Wszystkie te kategorie decydentów mogą wystąpić osobno lub łącznie (jedna osoba będąca jednocześnie mocodawca, sponsorem i ekspertem). Ponieważ ostateczne wyniki AHP zależą wyłącznie od osądów eksperckich, należy zaangażować specjalistów najbardziej obiektywnych i kompetentnych w zakresie rozważanego problemu decyzyjnego oraz mających dostęp do aktualnej wiedzy.

\section{PORÓWNANIA PARAMI}

Mając gotowy model hierarchiczny, należy go odpowiednio zanalizować, aby uzyskać dane liczbowe niezbędne do obliczenia współczynników wagowych, czyli priorytetów. Takiej analizy dokonuje się za pomocą specjalnej, dwubiegunowej skali, zwanej fundamentalną bądź dziewięciostopniową skalą porównań parami, na której zaznacza się stopień przewagi (bądź w

\footnotetext{
${ }^{19}$ G.A. Miller, The Magical Number Seven, Plus or Minus Two: Some Limits on our Capacity for Processing Information, „Psychological Review” 63/2 (1956), s. 81-97.

${ }^{20}$ T.L. Saaty, M.S. Ozdemir, Why the magic number seven plus or minus two, ,Mathematical and Computer Modelling" 38/3-4 (2003), s. 233-244.

${ }^{21}$ T.L. Saaty, Fundamentals of Decision Making...

${ }^{22}$ T.L. Saaty, Decision making with the analytic hierarchy process, „International Journal of Services Sciences" 2008/1, s. 83-98.

${ }^{23}$ A. Prusak, P. Stefanów, op. cit.
} 
zależności od problemu decyzyjnego - prawdopodobieństwa lub preferencji) jednego elementu nad drugim (rys. 2).

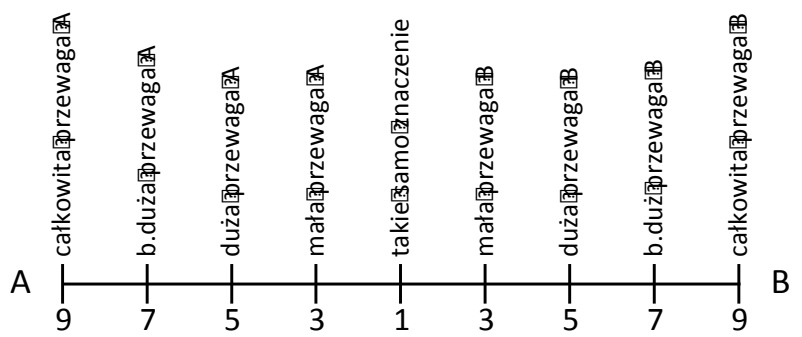

Rysunek 2. Dziewięciostopniowa skala porównań

Źródło: Opracowanie własne.

Przewagę tę można następująco określić zarówno werbalnie, jak i liczbowo:

- A i B mają takie samo znaczenie (,,1”, pośrodku skali);

- A ma małą przewagę nad B lub B ma małą przewagę nad A (,,3”, po lewej lub prawej stronie skali);

- A ma dużą przewagę nad B lub B ma dużą przewagę nad A (,,5”);

- A ma bardzo dużą przewagę nad B lub B ma bardzo dużą przewagę nad A (,,7’);

- A ma całkowitą przewagę nad B lub B ma całkowitą przewagę nad A (,9”).

Stopnie parzyste (oznaczone liczbowo jako 2, 4, 6, 8) można zaznaczyć „pomiędzy” głównymi kategoriami. Określane są one jako „wartości pośrednie” i respondent powinien je stosować tylko w wypadku, gdy nie jest pewny swojego osądu. Z powodu trudności w formułowaniu słownych określeń stopni parzystych (np. „między bardzo dużą a dużą przewaga") skala werbalna zawiera wyłącznie ,główne” kategorie, jak na rysunku 2, skala liczbowa natomiast może reprezentować wszystkie stopnie przewagi.

W celu dokonania poprawnej analizy hierarchii każdy element należy porównać z każdym innym znajdującym się w tej samej grupie modelu hierarchicznego. Liczba tak utworzonych par elementów $(N)$ może być policzona na podstawie następującego wzoru:

$$
N=\frac{n(n-1)}{2}
$$

gdzie:

n oznacza liczbę porównywanych elementów.

Z tego wzoru wynika, że duża liczba elementów niesie za sobą dużą liczbę porównań, a w konsekwencji ryzyko pomyłki podczas dokonywania tych porównań. Na przykład dla $\mathrm{n}=7$ elementów zostanie utworzonych 21 kombinacji, podczas gdy dla $n=10$ aż 45. Stąd już na etapie budowy hierarchii zaleca się, aby żadna grupa nie przekraczała 9 elementów, a najlepiej 7. Analiza modelu hierarchicznego za pomocą porównań parami zachodzi w układzie poszczególnych grup elementów z poziomu niższego, w odniesieniu do ich tak zwanego elementu macierzystego (wspólnego) znajdującego się na poziomie leżącym bezpośrednio wyżej w hierarchii. Na przykład kryteria analizowane są pod względem celu, subkryteria pod 
względem odpowiadających im kryteriów, natomiast warianty decyzyjne w odniesieniu do każdego subkryterium (lub kryterium, jeśli subkryteria nie zostały wydzielone).

\section{MACIERZ PRÓWNAŃ}

Wyniki porównań parami wprowadzane są ze skali (ankiety) do tak zwanej kwadratowej macierzy porównań A o wymiarach $(n \times n)$, gdzie $n$ jest liczbą porównywanych ze sobą elementów. Macierz A stanowi główne narzędzie analizy AHP i podstawę do obliczenia współczynników wagowych, czyli priorytetów ${ }^{24}$ :

$$
\mathbf{A}=\left[\begin{array}{cccc}
1 & a_{12} & \ldots & a_{1 n} \\
1 / a_{12} & 1 & \ldots & a_{2 n} \\
\vdots & \vdots & \vdots & \vdots \\
1 / a_{1 n} & 1 / a_{2 n} & \ldots & 1
\end{array}\right]
$$

Wyrazy leżące na przekątnej tej macierzy są zawsze jedynkami, gdyż elementy porównywane z samymi sobą muszą mieć ,jednakową ważność":

$$
a_{i j}=1, \quad \text { dla } \quad i=j
$$

Macierz ta jest odwrotnie symetryczna, co oznacza, że jeśli element A ma bardzo dużą przewagę nad B, czyli $A=7 \mathrm{~B}$, to $\mathrm{B}=1 / 7 \mathrm{~A}$. Macierzy tworzy się tyle, ile w modelu znajduje się grup elementów.

\section{PRIORYTETY}

Termin „priorytet” w ujęciu ogólnym oznacza coś, co ma pierwszeństwo, jest najważniejsze. W teorii AHP priorytety (priorities) to synonim współczynników wagowych (wag), niezależnie od miejsca danego elementu w rankingu ważności. Współczynniki wagowe w postaci wektorów W (w1, w2, w3) otrzymuje się po wykonaniu określonych operacji matematycznych na przedstawionej wcześniej macierzy porównań parami. Do tych operacji matematycznych zalicza się następujące sposoby obliczania współczynników wagowych:

- $\quad$ rachunek macierzowy;

- $\quad$ średnią arytmetyczną;

- $\quad$ średnią geometryczną.

Najprościej jest jednak skorzystać z oprogramowania komputerowego, na przykład Super Decisions. Wówczas dane pierwotne (porównania parami) wprowadza się bezpośrednio do specjalnej rubryki przypominającej dziewięciostopniową skalę porównań parami w układzie poziomym lub pionowym lub macierz (do wyboru użytkownika). Jeśli chodzi o „ręczne” procedury obliczania współczynników wagowych, to mnożenie macierzy pozwoli uzyskać najdokładniejsze wyniki, jednocześnie jest też najtrudniejsze od strony matematycznej i najbardziej czasochłonne. Dokładne omówienie procedur obliczania współczynników

\footnotetext{
${ }^{24}$ T.L. Saaty, Fundamentals of Decision Making and Priority...
} 
wagowych można znaleźć w literaturze przedmiotu ${ }^{25}$. Najpopularniejszym sposobem wyznaczenia wartości współczynników wagowych jest zastosowanie średniej geometrycznej (tab. 1). Twórca AHP zaleca jednak ostrożność przy stosowaniu tej metody, gdyż w wypadku liczby elementów większej niż 3 może ona generować niedokładne wynikii ${ }^{26}$.

Tabela 1. Ogólny schemat wyznaczania priorytetów za pomocą średniej geometrycznej dla $\mathrm{n}=3$ elementów

\begin{tabular}{|c|c|c|c|c|}
\hline \multicolumn{3}{|c|}{$\begin{array}{l}\text { Krok 1. Liczbowe wyniki } \\
\text { porównań parami wprowadza } \\
\text { się do kwadratowej macierzy A } \\
(\text { w tym wypadku } 3 \times 3) \text { : }\end{array}$} & \multirow{2}{*}{$\begin{array}{l}\text { Krok 2. Oblicza się średnie } \\
\text { geometryczne jako pierwiastek } n \text {-tego } \\
\text { stopnia }(\mathrm{n}=\text { liczba porównywanych } \\
\text { elementów, w tym wypadku } \mathrm{n}=3 \text { ) } \\
\text { iloczynu wyrazów macierzy } \mathrm{w} \\
\text { poszczególnych wierszach: } \\
r_{1}=\sqrt[z]{1 \times a_{12} \times a_{13}}\end{array}$} & \multirow{2}{*}{$\begin{array}{c}\text { Krok 4. Obliczamy } \\
\text { współczynniki wagowe } \\
\text { (priorytety) przez normalizację } \\
\text { wyników, czyli dzielenie } \\
\text { wartości poszczególnych } \\
\text { pierwiastków przez ich sume } \\
\text { (suma tych współczynników } \\
\text { powinna na końcu wynosić 1): } \\
w_{1}=r_{1}\end{array}$} \\
\hline 1 & $a_{12}$ & $a_{13}$ & & \\
\hline $1 / a_{12}$ & 1 & $a_{2: 3}$ & $r_{2}=\sqrt[n]{1 / a_{12} \times 1 \times a_{23}}$ & $w_{2}=r_{2}$ \\
\hline $1 / a_{13}$ & $1 / a_{23}$ & 1 & $r_{3}=\sqrt[5]{1 / a_{13} \times 1 / a_{13} \times 1}$ & $w_{3}=r_{3}$ \\
\hline \multicolumn{3}{|c|}{$\begin{array}{r}\text { Krok 3. Sumujemy średnie } \\
\text { geometryczne: }\end{array}$} & $\sum_{i=1}^{3}$ & $\sum_{i=1}^{3} w_{i}=1$ \\
\hline
\end{tabular}

Źródło: Opracowanie własne.

W literaturze dotyczącej AHP można się spotkać z pojęciem priorytetów lokalnych i globalnych. Priorytety lokalne i globalne odnoszą się do ich ,miejsca” w układzie hierarchicznym i relacji do celu decyzyjnego. Priorytety lokalne to współczynniki wagowe, które zostały uzyskane bezpośrednio z macierzy porównań. Ukazują one znaczenie danego elementu względem elementu macierzystego (położonego o poziom wyżej w hierarchii). Priorytety globalne natomiast przedstawiają udział każdego elementu w realizacji celu, czyli elementu znajdującego się na najwyższym poziomie struktury decyzyjnej. Na przykład priorytety globalne dla subkryteriów obliczane są jako iloczyn ich wag lokalnych oraz wag ich macierzystych kryteriów. W literaturze można się także spotkać z pojęciem priorytetów idealnych. To pojęcie łączone jest ze zjawiskiem zwanym inwersją rang (rank reversal), a polegającym na tym, że pierwotnie wyznaczona kolejność (ranga) poszczególnych elementów

\footnotetext{
${ }^{25}$ Na przykład A. Ishizaka, A. Labib, Selection of new production facilities with the Group Analytic Hierarchy Process Ordering method, „Expert Systems with Applications” 38/6 (2011), s. 73177325; T.L. Saaty, A ratio scale metric and the compatibility of ratio scales: The possibility of arrow's impossibility theorem, „Applied Mathematics Letters” 7/6 (1994), s. 45-49; idem, Decision Making For Leaders, RWS Publications, Pittsburgh 2012.

${ }^{26}$ T.L. Saaty, Decision Making For Leaders...
} 
(wynikająca z wartości ich współczynników wagowych) może ulec zmianie w konsekwencji wykluczenia jednego $\mathrm{z}$ nich lub wprowadzenia do modelu nowego, nawet neutralnego, elementu $^{27}$. Aby zapobiec temu zjawisku, priorytety mogą być przedstawione w trybie idealnym (w odróżnieniu od tradycyjnego, zwanego dystrybutywnym) ${ }^{28}$. Termin ,idealny” odnosi się do elementu najważniejszego w danym zbiorze. Wartości wag pozostałych elementów dzieli się przez ten najwyższy priorytet, który wówczas przyjmuje wartość „1”. Program Super Decisions automatycznie podaje wartości priorytetów zarówno w trybie dystrybutywnym, jak i idealnym.

\section{NIEZGODNOŚĆ}

Jedną z największych zalet metody AHP jest mechanizm pozwalający na weryfikację logiczności (spójności, zgodności) priorytetów, które zostały obliczone na podstawie wyników porównań parami. Jak wspomniano w poprzednich częściach artykułu, konieczność uwzględnienia wszystkich kombinacji par podczas dokonywania porównań powoduje, że w wypadku dużej liczby elementów istnieje duże ryzyko otrzymania nielogicznych (niespójnych) osądów na skutek błędów popełnianych przez respondentów. Błędy te wynikają głównie ze spadku koncentracji i znużenia dużą liczbą porównań tych samych elementów ze sobą w różnych konfiguracjach. Dlatego z jednej strony redundancja (nadmiarowość) porównań traktowana jest jako zaleta metody pozwalająca sprawdzić, w jakim stopniu eksperci są spójni w swoich osądach, a $\mathrm{z}$ drugiej strony postrzegana jest jako wada, obniżająca jakość otrzymanych wyników. Stopień logiczności dokonanych porównań mierzony jest za pomocą specjalnego instrumentu, zwanego współczynnikiem zgodności (CR, Consistency Ratio). Współczynnik CR wyznaczany jest na każdym etapie obliczania współczynników wagowych, czyli dla każdej macierzy. W programie Super Decisions jego wartość pojawia się automatycznie, ale współczynnik CR można również wyznaczyć „ręcznie”. Dokładny algorytm obliczania CR został przedstawiony na przykład w publikacji autorstwa Prusak i Stefanów ${ }^{29}$. Ogólnie natomiast przedstawiono go w tabeli 2.

Zgodnie z zaleceniami twórcy AHP, aby uznać wyniki za zgodne, wartość współczynnika CR nie może przekroczyć 0,10 (10\%). Jednakże w wypadku mniejszej liczby elementów tolerowana wartość CR jest jeszcze bardziej restrykcyjna i wynosi 0,05 (5\%) dla $n=3$ elementów oraz $0,08(8 \%)$ dla $n=4$ elementów $^{30}$. W literaturze przedmiotu za wartość „graniczną" przyjmuje się jednak CR $=0,10$, niezależnie od liczby elementów. Jeśli CR przekroczy ten poziom, porównania należy uznać za niezgodne i sugeruje się powtórzenie analizy $^{31}$. Współczynnik CR i przyczyny występowania niezgodności są najczęściej badanymi

\footnotetext{
${ }^{27}$ V. Belton, T. Gear, On a short-coming of Saaty's method of analytic hierarchies, „Omega” 11/3 (1983), s. 228-230.

${ }^{28}$ T.L. Saaty M. Sagir, An essay on rank preservation and reversal, ,Mathematical and Computer Modelling" 49/5-6 (2009), s. 1230-1243; T.L. Saaty, L.G. Vargas, Experiments on rank preservation and reversal in relative measurement, „Mathematical and Computer Modelling” 17/45 (1993), s. 13-18.

${ }^{29}$ A. Prusak, P. Stefanów, AHP - analityczny proces hierarchiczny...

${ }^{30}$ T.L. Saaty, Fundamentals of Decision Making and Priority...

${ }^{31}$ T.L. Saaty, L.G. Vargas, The Logic of Priorities...
} 
aspektami metody AHP. W tym zakresie badacze próbowali znaleźć odpowiedź na trzy pytania badawcze, które można streścić następująco ${ }^{32}$ :

- Czy ustalona na poziomie 0,10 (10\%) wartość współczynnika CR nie jest zbyt restrykcyjna i czy powinna być traktowana jedynie jako wskazówka do ewentualnego powtórzenia badań, czy też jako sztywna reguła ${ }^{33}$ ?

- Czy współczynnik CR jest odpowiednią miarą poziomu logiczności osądów ${ }^{34}$ ?

- Czy można zredukować współczynnik CR za pomocą odpowiednich procedur matematycznych, bez naruszania danych wejściowych ${ }^{35}$ ?

Tabela 2. Ogólny schemat wyznaczania współczynnika zgodności (CR, Consistency Ratio)

\begin{tabular}{|c|c|}
\hline $\begin{array}{l}\text { Krok 1: Wyznacza się tzw. największą wartość własną }\left(\lambda_{\max }\right) \text { macierzy } \\
\mathbf{A} \text {, w uproszczony sposób obliczana jest ona jako suma iloczynów sumy } \\
\text { wartości porównań w każdej kolumnie macierzy } \mathbf{A} \text { oraz odpowiedniego } \\
\text { dla danego elementu współczynnika wagowego: }\end{array}$ & $\lambda_{\max }=\sum_{i=1}^{n} \sum_{j=1}^{n} a_{i j} \cdot w_{i}$ \\
\hline $\begin{array}{l}\text { Krok 2: Oblicza się tzw. indeks niezgodności (IC, Inconsistency Index) } \\
\text { będący ilorazem różnicy największej wartości własnej macierzy i liczby } \\
\text { porównywanych elementów }(n) \text { przez różnicę }(n-1) \text { : }\end{array}$ & $I C=\left(\lambda_{\max }-n\right) /(n-1)$ \\
\hline 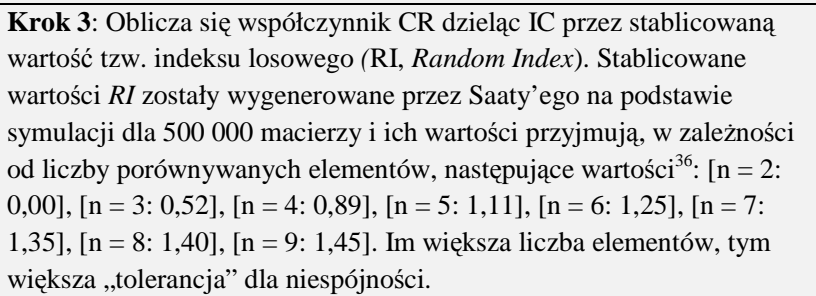 & $C / R I$ \\
\hline
\end{tabular}

Zródło: Opracowanie własne.

Na te pytania nadal nie udzielono jednoznacznej odpowiedzi, a uzyskanie odpowiednio niskiego współczynnika CR pozostaje jednym z największych wyzwań metody AHP.

\section{ANALIZA WRAŻLIWOŚCI}

Oprócz kontroli zgodności, należy przeprowadzić analizę wrażliwości wyników AHP, która pozwala na zbadanie wpływu zmiany wartości macierzy na wyniki końcowe zarówno współczynników wagowych (priorytetów), jak i współczynnika CR. Metoda AHP jest zazwyczaj bardzo wrażliwa nawet na niewielkie zmiany wartości porównań. Analiza

32 A. Prusak, P. Stefanów, Badania nad wtaściwościami operacyjnymi metody AHP, „Folia Oeconomica Cracoviensia" 2011/52, s. 87-104.

${ }^{33}$ B. Apostolou, J.M. Hassell, An empirical examination of the sensitivity of the analytic hierarchy process to departures from recommended consistency ratios, „Mathematical and Computer Modelling" 17/4-5 (1993), s. 163-170.

${ }^{34}$ J.A. Alonso, M.T. Lamata, Consistency in the Analytic Hierarchy Process - A New Approach, „International Journal of Uncertainty, Fuzziness and Knowledge-Based Systems” 14/4 (2006), s. $445-459$.

${ }^{35}$ J.S. Finan, W.J. Hurley, The analytic hierarchy process: Does adjusting a pairwise comparison matrix to improve the consistency ratio help?, „Computers \& Operations Research” 24/8 (1997), 749-755.

${ }^{36}$.A. Alonso, M.T. Lamata, A Statistical Criterion of Consistency in the Analytic Hierarchy Process, „Modeling Decisions for Artificial Intelligence 2005/3558, s. 67-76. 
wrażliwości pomoże odpowiedzieć na pytanie, który element macierzy ma największy wpływ na wysokość współczynnika CR. Program Super Decisions ma odrębną funkcję analizy wrażliwości, natomiast procedury ręczne omówiili na przykład Prusak i Stefanów oraz Saaty ${ }^{37}$.

\section{WIELOKRYTERIALNE METODY PODEJMOWANIA DECYZJ}

Wielokryterialne metody podejmowania decyzji stosowane są do rozwiązywania ważnych, złożonych problemów decyzyjnych. W praktyce ważne decyzje nigdy nie zapadają jednoosobowo, lecz przy udziale wieloosobowych zespołów, złożonych z ekspertów z różnych dziedzin. Znane są dwa sposoby łączenia wyników pochodzących od wielu respondentów: jakościowe (behawioralne) oraz ilościowe (matematyczne) ${ }^{38}$. W odniesieniu do metody AHP opisywane są cztery sekwencyjne ścieżki agregacji wyników grupowych ${ }^{39}$ :

- konsensus;

- głosowanie;

- agregacja indywidualnych osądów (AIJ, aggregating individual judgments);

- agregacja indywidualnych priorytetów (AIP, aggregating individual priorities).

W pierwszej kolejności należy dążyć do osiągnięcia konsensusu. Jedną z najbardziej popularnych, usystematyzowanych metod grupowego podejmowania decyzji prowadzących z założenia do osiagnięcia konsensusu jest metoda delficka ${ }^{40}$. Technika ta jest stosunkowo często łączona z AHP ${ }^{41}$. Jeśli z jakichś powodów nie jest możliwe osiągnięcie konsensusu, wówczas powinno się przeprowadzić głosowanie, a jeśli również to nie odniesie skutku, pozostają metody matematyczne oparte na średnich arytmetycznej i geometrycznej. W wypadku metody AHP są to szeroko omawiane w literaturze procedury AIJ oraz AIP ${ }^{42}$. Różnica między AIJ a AIP wynika z formy udziału indywidualnych osób w procesie decyzyjnym - czy działają one jako jednolity zespół, czy jako niezależni respondenci. Dlatego wybór matematycznej metody agregacji wyników powinien być dostosowany do sytuacji i charakteru grupy. Jeśli grupa osób ściśle ze sobą współpracuje, działając jako jednolity zespół, należy ich potraktować jako ,nowego decydenta” i zastosować procedurę AIJ, uśredniając wyniki poszczególnych członków zespołu już na etapie porównań parami. W rezultacie powstanie nowa, zagregowania struktura hierarchiczna. Podejście AIJ obwarowane jest jednak pewnymi ograniczeniami, na przykład wymóg dotyczący homogeniczności (jednorodności) osądów ${ }^{43}$.

\footnotetext{
${ }^{37}$ A. Prusak, P. Stefanów, AHP - analityczny proces hierarchiczny...; T.L. Saaty, Fundamentals of Decision Making and Priority...

${ }^{38}$ P. Goodwin, G. Wright, Analiza decyzji, wyd. 1, Walters Kluwer Polska, Warszawa 2011.

${ }^{39}$ R.F. Dyer, E.H. Forman, op. cit.

${ }^{40}$ H.A. Linstone, M. Turoff, The Delphi Method: Techniques and Applications, red. H.A. Linstone, M. Turoff, wyd. 1, New Jersey 1975.

${ }^{41}$ M. Kim, Y.-C. Jang, S. Lee, Application of Delphi-AHP methods to select the priorities of WEEE for recycling in a waste management decision-making tool, „Journal of Environmental Management” 2013/128, s. 941-948; M. Tavana, D.T. Kennedy, J. Rappaport, Y.J. Ugras, An AHPDelphi Group Decision Support System Applied to Conflict Resolution in Hiring Decisions, „Journal of Management Systems" 5/1 (1993), s. 49-74.

${ }^{42}$ T.L. Saaty, K. Peniwati, Group Decision Making: Drawing out and Reconciling Differences, wyd. 1, RWS Publications, Pittsburgh 2007.

${ }^{43}$ Należy pamiętać, że homogeniczność osądów nie ma nic wspólnego z zasadą homogeniczności, stanowiącą o podobieństwie elementów w grupach struktury hierarchicznej. R. Lin, J.S.-J. Lin, J.
} 
Jeśli respondenci są niezależni i nie stanowią jednolitego zespołu, należy zastosować podejście AIP, polegające na uśrednieniu ich indywidualnych, końcowych priorytetów. Ze względu na większą swobodę stosowania procedury AIP jest ona stosowana znacznie częściej, niezależnie od charakteru grupy decyzyjnej ${ }^{44}$. W procedurze AIJ zalecana jest średnia geometryczna, natomiast podejście AIP dopuszcza średnią geometryczną lub arytmetyczną ${ }^{45}$. Jeśli eksperci w danej grupie różnią się znacznie na przykład pod względem poziomu wykształcenia czy doświadczenia, a w związku z tym można przypuszczać, że opinie jednych są ważniejsze od innych, stosuje się średnie ważone. Wówczas priorytety lub osądy ekspertów z wyższym poziomem wiedzy otrzymują wyższe wagi.

\section{WNIOSKI}

Struktura artykułu została zbudowana wokół kilku krótkich, kluczowych haseł związanych z metodą AHP, jakimi są: ,hierarchia”, ,eksperci-decydenci”, ,porównania parami”, ,macierz porównań”, „priorytety”, „niezgodność”, ,analiza wrażliwości” oraz „,decyzje grupowe”. Znajomość każdego z tych zagadnień jest niezbędna dla wszystkich użytkowników metody AHP. Niniejszy artykuł nie tylko przedstawia definicje tych pojęć, ale i dokładnie omawia problemy z nimi związane, jakie mogą się pojawić w procesie rozwiązywania problemów decyzyjnych. Autorzy odwołali się także do najważniejszych pozycji literaturowych i odnieśli się do badań naukowych, jakie były dotychczas prowadzone w prezentowanych tematach. Wiele tych badań dotyczy problemu niezgodności (niespójności, nielogiczności), mierzonej za pomocą specjalnego współczynnika CR. Kontrola niezgodności jest integralną częścią metody AHP, jednakże sprawia najwięcej problemów: odpowiedzi niespójne $(\mathrm{CR}>0,10)$ należy odrzucić. Dlatego mimo wielu dotychczasowych badań tym zakresie sposoby redukcji niezgodności, na różnych etapach AHP, wciąż pozostawiają otwarte pole do działań badawczych.

\section{LITERATURA}

[1] Alonso J.A., Lamata M.T., A Statistical Criterion of Consistency in the Analytic Hierarchy Process, „Modeling Decisions for Artificial Intelligence 2005/3558, s. 6776.

[2] Alonso J.A., Lamata M.T., Consistency in the Analytic Hierarchy Process - A New Approach, ,International Journal of Uncertainty, Fuzziness and Knowledge-Based Systems" 14/4 (2006), s. 445-459.

[3] Apostolou B., Hassell J.M., An empirical examination of the sensitivity of the analytic hierarchy process to departures from recommended consistency ratios, „Mathematical and Computer Modelling” 17/4-5 (1993), s. 163-170.

[4] Belton V., Gear T., On a short-coming of Saaty's method of analytic hierarchies, „Omega” 11/3 (1983), s. 228-230.

Chang, D. Tang, H. Chao, P.C. Julian, Note on group consistency in analytic hierarchy process, „European Journal of Operational Research” 190/3 (2008), s. 672-678.

${ }^{44}$ R. Ramanathan, L.S. Ganesh, Group preference aggregation methods employed in AHP: An evaluation and an intrinsic process for deriving members' weightages, „European Journal of Operational Research" 79/2 (1994), s. 249-265.

${ }^{45}$ E. Forman, K. Peniwati, Aggregating individual judgments and priorities with the analytic hierarchy process, „European Journal of Operational Research” 108/1 (1998), 165-169. 
[5] Dyer R.F., Forman E.H., Group decision support with the Analytic Hierarchy Process, „Decision Support Systems” 8/2 (1992), s. 99-124.

[6] Finan J.S., Hurley W.J., The analytic hierarchy process: Does adjusting a pairwise comparison matrix to improve the consistency ratio help?, „Computers \& Operations Research" 24/8 (1997), 749-755. doi:10.1016/S0305-0548(96)00090-1

[7] Forman E.H., Facts and fictions about the analytic hierarchy process, „Mathematical and Computer Modelling" 17/4-5 (1993), s. 19-26.

[8] Forman E.H., Gass S. I., The Analytic Hierarchy Process - An Exposition, „Operations Research” 49/4 (2001), s. 469-486.

[9] Forman E., Peniwati K., Aggregating individual judgments and priorities with the analytic hierarchy process, „European Journal of Operational Research” 108/1 (1998), 165-169.

[10] Gao L., Hailu A., Identifying preferred management options: An integrated agentbased recreational fishing simulation model with an AHP-TOPSIS evaluation method, „Ecological Modelling” 2013/249, s. 75-83.

[11] Goodwin P., Wright G., Analiza decyzji, wyd. 1, Walters Kluwer Polska, Warszawa 2011.

[12] Ishizaka A., Labib A., Selection of new production facilities with the Group Analytic Hierarchy Process Ordering method, „Expert Systems with Applications” 38/6 (2011), s. 7317-7325.

[13] Kim M., Jang Y.-C., Lee S., Application of Delphi-AHP methods to select the priorities of WEEE for recycling in a waste management decision-making tool, „Journal of Environmental Management” 2013/128, s. 941-948.

[14] Labaree L.W., Mr. Franklin: A Selection from His Personal Letters by Benjamin Franklin, red. L.W. Labaree, W.J. Bell, Yale University Press, New Haven 1956.

[15] Lin R., Lin J.S.-J., Chang J., Tang D., Chao H., Julian P.C., Note on group consistency in analytic hierarchy process, „European Journal of Operational Research"190/3 (2008), s. 672-678.

[16] Linstone H.A., Turoff M., The Delphi Method: Techniques and Applications, red. H.A. Linstone, M. Turoff, wyd. 1, New Jersey 1975.

[17] Miller G.A., The Magical Number Seven, Plus or Minus Two: Some Limits on our Capacity for Processing Information, „Psychological Review” 63/2 (1956), s. 81-97.

[18] Prusak A., Stefanów P., Badania nad właściwościami operacyjnymi metody AHP, „Folia Oeconomica Cracoviensia” 2011/52, s. 87-104.

[19] Prusak A., Stefanów P., AHP - analityczny proces hierarchiczny. Budowa i analiza modeli decyzyjnych krok po kroku, wyd. 1, C.H. Beck, Warszawa 2014.

[20] Ramanathan R., Ganesh L.S., Group preference aggregation methods employed in AHP: An evaluation and an intrinsic process for deriving members' weightages, „European Journal of Operational Research” 79/2 (1994), s. 249-265.

[21] Roy B., Paradigms and Challenges. In Multiple Criteria Decision Analysis: State of the Art Surveys, „International Series in Operations Research \& Management Science" 2005/78, s. 3-24.

[22] Saaty T.L., A ratio scale metric and the compatibility of ratio scales: The possibility of arrow's impossibility theorem, ,Applied Mathematics Letters” 7/6 (1994), s. 4549.

[23] Saaty T.L., Fundamentals of Decision Making and Priority Theory with the Analytic Hierarchy Process, wyd. 2, RWS Publications, Pittsburgh 2000. 
[24] Saaty T.L., Decision making with the analytic hierarchy process, „International Journal of Services Sciences" 2008/1, s. 83-98.

[25] Saaty T.L., Decision Making For Leaders, RWS Publications, Pittsburgh 2012.

[26] Saaty T.L., Forman E.H., The Hierarchon: A Dictionary of Hierarchies, RWS Publications, Pittsburgh 1992.

[27] Saaty T.L., Ozdemir M.S., Why the magic number seven plus or minus two, „Mathematical and Computer Modelling” 38/3-4 (2003), s. 233-244.

[28] Saaty T.L., Peniwati K., Group Decision Making: Drawing out and Reconciling Differences, wyd. 1, RWS Publications, Pittsburgh 2007.

[29] Saaty T.L., Sagir M., An essay on rank preservation and reversal, „Mathematical and Computer Modelling" 49/5-6 (2009), s. 1230-1243.

[30] Saaty T.L., Vargas L.G., Experiments on rank preservation and reversal in relative measurement, ,Mathematical and Computer Modelling” 17/4-5 (1993), s. 13-18.

[31] Sinuany-Stern Z., An AHP/DEA methodology for ranking decision making units, „International Transactions in Operational Research" 7/2 (2000), s. 109-124.

[32] Tavana M., Kennedy D.T., Rappaport J., Ugras Y.J., An AHP-Delphi Group Decision Support System Applied to Conflict Resolution in Hiring Decisions, „Journal of Management Systems” 5/1 (1993), s. 49-74.

[33] Vaidya O.S., Kumar S., Analytic hierarchy process: An overview of applications, „European Journal of Operational Research” 169/1 (2006), s. 1-29.

[34] Vidal L.-A., Marle F., Bocquet J.-C., Using a Delphi process and the Analytic Hierarchy Process (AHP) to evaluate the complexity of projects, „Expert Systems with Applications" 38/5 (2011), s. 5388-5405.

\section{ANALITYC HIERARCHY PROCESS (AHP) FOR SHORTCUT - KEY CONCEPTS AND LITERATURE}

Today quite a common direction of research activity and implementation processes is analysing a new methods or new ways of using known methods. This issue was addressed in this article. The presented analysis is one of the well-known methods used in the decision-making process. It is the AHP (Analytic Hierarchy Process). In Poland it is a relatively new subject of research, but as if it is going about the implementation in the practice this is a new area. Specifically, the article provides a review of the method, showing the most important information for test takers. Of particular interest seems to be the use of this method in strategic management (strategic decision making) in public institutions and in the larger business units as well.

The objective of this paper is to present and explain the key terms related to one of the most popular decision support methods, the Analytic Hierarchy Process (AHP). The AHP was created in the 70' by the American mathematician, Thomas L. Saaty. The paper discusses the main themes related to the AHP, specifically: "hierarchy", "expert-decision maker", "pairwise comparisons", "priorities", "inconsistency", "sensitivity analysis" and "group decisions". Each theme is carefully discussed with relation to their application problems and relevant literature sources have been also provided.

Keywords: analytic hierarchy process, AHP, consistency, CR, group decisions, decision-makers.

DOI:10.7862/rz.2014.hss.66

Przesłano do redakcji: czerwiec 2014

Przyjęto do druku: grudzień 2014 